\title{
Experimental and Mathematical Optimization of the $\beta$-Sitosterol extraction from Mechanically Activated Pine Bark
}

\author{
Vladislav A. Ionin*a, b, Aleksandr S. Kazachenko ${ }^{a}$, b, \\ Andrei M. Skripnikov ${ }^{\text {a, b}}$, Evgeniia V. Veprikova ${ }^{a}$, \\ Mikhail Yu. Belash ${ }^{\mathrm{a}}$ and Oxana P. Taran ${ }^{\mathrm{a}, \mathrm{b}}$ \\ ${ }^{a}$ Institute of Chemistry and Chemical Technology SB RAS \\ Krasnoyarsk, Russian Federation \\ ${ }^{b}$ Siberian Federal University \\ Krasnoyarsk, Russian Federation
}

Received 12.05.2021, received in revised form 10.07.2021, accepted 04.09.2021

\begin{abstract}
The optimization of the process of $\beta$-sitosterol extraction from the original and activated with two different methods (drum mill, explosive autohydrolysis) pine bark was carried out. The effect of the duration of the extraction process and the concentration of $\mathrm{NaOH}$ in the saponification solution on the yield of $\beta$-sitosterol was explored. The concentration of $\mathrm{NaOH}$ in the saponification solution appeared to have the highest effect on the $\beta$-sitosterol yields from activated pine bark. Mechanical activation of pine bark significantly increased the yield of $\beta$-sitosterol and reduced the duration of the isolation process. The highest yield of $\beta$-sitosterol was achieved with the use of pine bark activated by explosive autohydrolysis. According to the proposed mathematical model, the maximum predicted value of the $\beta$-sitosterol yield from this sample is 0.078 (wt\%). This could be achieved using the process duration 10.3 hours and a $0.5 \mathrm{~N}$ solution of $\mathrm{NaOH}$. This yield is close to the content of $\beta$-sitosterol in the original pine bark.
\end{abstract}

Keywords: pine bark, beta-sitosterol, mechanical activation, explosive autohydrolysis, extraction, optimization.

Citation: Ionin V.A., Kazachenko A.S., Skripnikov A.M., Veprikova E.V., Belash M. Yu., Taran O.P. Experimental and mathematical optimization of the $\beta$-sitosterol extraction from mechanically activated pine bark, J. Sib. Fed. Univ. Chem., 2021, 14(3), 302-314. DOI: 10.17516/1998-2836-0248

(C) Siberian Federal University. All rights reserved

This work is licensed under a Creative Commons Attribution-NonCommercial 4.0 International License (CC BY-NC 4.0).

* Corresponding author E-mail address: ionin.va@icct.krasn.ru 


\title{
Экспериментальная и математическая
}

\section{оптимизация процесса выделения $\beta$-ситостерина \\ из механически активированной коры сосны}

\author{
В. А. Ионин ${ }^{\mathrm{a}, \boldsymbol{\sigma}}$, А.С. Казаченко ${ }^{\mathrm{a}, \boldsymbol{\sigma}}$, А. М. Скрипников ${ }^{\mathrm{a}, \boldsymbol{0}}$, \\ Е.В. Веприкова ${ }^{\mathrm{a}}$ М. Ю. Белаш ${ }^{\mathrm{a}}$, О. П. Таран ${ }^{\mathrm{a}, \boldsymbol{\sigma}}$ \\ ${ }^{a}$ Институт химии и химической технологии \\ ФИЦ КНЦ СО РАН \\ Российская Федераџия, Красноярск \\ ${ }^{6}$ Сибирский федеральный университет \\ Российская Федерация, Красноярск
}

\begin{abstract}
Аннотация. В работе проведена оптимизация процесса выделения $\beta$-ситостерина из исходной и предварительно активированной двумя способами (барабанная мельница, взрывной автогидролиз) коры сосны. Установлено влияние продолжительности процесса и концентрации $\mathrm{NaOH}$ в омыляющем растворе на выход $\beta$-ситостерина. Показано, что при использовании предварительно активированной коры сосны наибольшее влияние на процесс выделения $\beta$-ситостерина оказывает концентрация $\mathrm{NaOH}$ в омыляющем растворе. Механическая активация коры сосны позволяет существенно увеличить выход $\beta$-ситостерина и уменьшить продолжительность процесса его выделения. Наибольший выход $\beta$-ситостерина достигается при использовании коры сосны, предварительно активированной взрывным автогидролизом. Согласно полученной математической модели максимальное значение выхода $\beta$-ситостерина из этого образца коры составляет 0,078 мас.\%, что достигается при продолжительности процесса 10,3 ч и использовании 0,5 н NaOH. Этот выход близок к содержанию $\beta$-ситостерина в исходной коре сосны.
\end{abstract}

Ключевые слова: кора сосны, бета-ситостерин, механическая активация, взрывной автогидролиз, экстракция, оптимизация.

Цитирование: Ионин, В.А. Экспериментальная и математическая оптимизация процесса выделения $\beta$-ситостерина из механически активированной коры сосны / В.А. Ионин, А.С. Казаченко, А. М. Скрипников, Е.В. Веприкова, М.Ю. Белаш, О.П. Таран // Журн. Сиб. федер. ун-та. Химия, 2021, 14(3). С. $302-314$. DOI: $10.17516 / 1998-2836-0248$

\section{Introduction}

Coniferous forests occupy the largest forest area in Siberia. This is also typical for the Krasnoyarsk region, which is dominant in the Russian forest industry. The total timber stock in the region is 11.5 billion cubic meters, including 9.5 billion cubic meters of coniferous wood [1,2]. The most economically valuable is pine, which ranks first in terms of timber harvesting and makes up about $70 \%$ of the harvested wood raw material[1,2]. Almost three quarters of the about 60 million cubic meters of wood waste generated annually comes from sawmilling. An analysis of the raw materials usage at the

$$
-303-
$$


enterprises of the Krasnoyarsk region showed a low yield of sawn timber production (45-47 \%) and, accordingly, large volumes of waste (47-49\%), which are not used rationally [2].

Extraction of high valuable substances from plant biomass waste is a topical trend [3-5] intensively developing method. It exists within the framework of «green chemistry» focusing on the design wastefree chemical production without use of harmful substances, aggressive conditions and, finally, safe for the environment [6]. One of the most valuable substances in the pine bark is $\beta$-sitosterol, which is biologically active and widely used as food additive decreasing blood cholesterol levels as well as component of anticancer drugs [7-10]. The extraction of resinous organic substances (with hexane, ether, etc.)is traditionally used for $\beta$-sitosterol isolation from bark.This is followed by saponification and $\beta$-sitosterol separation from the resulting mixture [11-13].

For the most complete isolation of resinous substances, the fine grinding the solid bark biomass is necessary, which is often achieved by methods of mechanical activation. Mechanochemical processes occurring during the activation of materials contribute to the deep integrated bark and wood waste processing $[5,14]$. The decomposition of thermally unstable components of materials is prevented during activation due to the non-thermal nature of the action, while changes in the electronic structures of the resulting compounds take place with an increase in extractability of substances from biomass materials $[5,15]$.

The aim of this work was to optimize the process of $\beta$-sitosterol isolation from pine bark, activated by different methods (in a drum mill or by the explosive autohydrolysis method). The process of isolation includes the following steps: mechanical activation of grinded bark, extraction of resinous substances with hexane, saponification of the obtained resinous substances with alcohol solutions of $\mathrm{NaOH}$, extraction of $\beta$-sitosterol. The influence on the target product yield of such factors as the method of mechanical activation, the extraction time with hexane, as well as a concentration of $\mathrm{NaOH}$ alcoholic solution in the saponification process experimentally was studied. In addition, numerical optimization of the process was carried out.

\section{Materials and methods}

\section{Preparation and mechanical activation of pine bark}

Samples of pine bark used in this work, obtained as follows: 1) air-dry pine bark was grinded on a rotary knife mill RM-120 (Vibrotechnik, St. Petersburg) using unloading sieves with a mesh of $3 \mathrm{~mm}$ (sample Original); 2) grinded pine bark sample was activated in a laboratory drum mill ML-1 type(Promstroymash, Kaluga) for 1 hour at room temperature, rotation speed $72 \mathrm{rpm}$, using porcelain balls with a displaced center of gravity (sample MCA); 3) grinded pine bark sample activated by explosive autohydrolysis using a stationary equipment produced by the Institute of Chemistry an Chemical Technology SB RAS [11] at $120^{\circ} \mathrm{C}$, water vapor pressure 1,0 MPa and $30 \mathrm{~s}$ activation time (sample VAG). Each bark sample was dried in an oven at a temperature of $100-105{ }^{\circ} \mathrm{C}$ until the moisture content in the samples was $<1 \%$.

\section{Extraction of resinous substances}

Pine bark samples were extracted using hexane until complete removal of the resinous substances in a $250 \mathrm{ml}$ Soxhlet apparatus at $65-70{ }^{\circ} \mathrm{C}$ for $4-16$ hours. The solvent was evaporated from the obtained extracts using a rotary evaporator, and the solid residue was dried in an oven at a temperature 
of $100-105{ }^{\circ} \mathrm{C}$ to constant weight. Then the resinous substances yield was determined in terms of absolute dry pine barksample. Three parallel experiments were carried out to average the results.

Saponification of resinous substances.

Extraction with diethyl ether

The resinous substances were saponified by dissolving in $100 \mathrm{ml}$ of a $\mathrm{NaOH}$ alcohol solution with a concentration of $0.50,0.75$, and $1.00 \mathrm{~N}$ while heating in an Erlenmeyer flask placed in a sand bath at $65-70{ }^{\circ} \mathrm{C}$ for $1 \mathrm{~h}$. The resulting solutions was diluted 4 times with water. The unsaponifiable substances separation was conducted by triple extraction with diethyl ether in a separatory funnel. The ether fractions were combined, frozen at $-10^{\circ} \mathrm{C}$, and analyzed.

\section{GC-MS identification and quantative analysis}

The qualitative and quantitative analysis of the unsaponifiable resinous components of pine bark obtained by extraction with diethyl ether was carried out on an Agilent 7890A gas chromatograph with an Agilent 7000A quadrupole mass detector using an HP-5ms capillary column $30 \mathrm{~mm} \times 0.25$ $\mathrm{mm} \times 0.25 \mu \mathrm{m}$. Temperature program: initial column temperature $40{ }^{\circ} \mathrm{C}$, isotherm for 4 minutes, with a rise rate of $7{ }^{\circ} \mathrm{C} / \mathrm{min}$ up to $250{ }^{\circ} \mathrm{C}$, up to $300{ }^{\circ} \mathrm{C}$ with a rise rate of $4{ }^{\circ} \mathrm{C} / \mathrm{min}$, isotherm at $300{ }^{\circ} \mathrm{C}$ for $15 \mathrm{~min}$. The carrier gas (helium) flow rate through the column is $1 \mathrm{~cm}^{3} / \mathrm{min}$. Evaporator temperature $300{ }^{\circ} \mathrm{C}$, interface temperature $300{ }^{\circ} \mathrm{C}$. The total analysis time was 61.5 minutes. Recorded mass chromatograms obtained in the following mode: $\mathrm{m} / \mathrm{z}$ scanning in range from 40 to 450 , data acquisition time $0.1 \mathrm{~s}$, electron ionization energy $70 \mathrm{eV}$, quadrupole temperature $150{ }^{\circ} \mathrm{C}$, ion source $230^{\circ} \mathrm{C}$. Individual compounds identified using the NIST MS Search 2.0 instrument database.

Mathematical optimization of the $\beta$-sitosterol isolation process was carried out using Statgraphics Centurion XVI, DOE block (Design of Experiment) software according to the procedure described in $[16,17]$.

\section{Results and discussion}

\section{Mechanical activation of pine bark}

It is well known that the mechanical activation of solids is a technique leading to the transformation of their structure, accompanied by significant changes in composition and chemical properties. For example, in the process of wood raw materials explosive autohydrolysis (VAG) mechanical destruction of particles and organic substances thermochemical transformations in the biomass occurs under increased temperature and pressure in a water vapor the thermochemical transformations play a vital role in increasing the reactivity at solids [18]. Under high pressures stress field is formed in certain areas of solids, creating new surfaces, active centers and forming more reactive structures. Mechanochemical activation of plant raw materials in mills also leads not only to the grinding of particles, but also to the transformation of the structure of biopolymers (lignin, cellulose, etc.) [5, 14]. However, in this case, it is not possible to achieve the effect of high-pressure exposure, which is characteristic for the explosive autohydrolysis.

We studied earlier the effect of various activation methods (explosive autohydrolysis and activation in a drum mill) and activation conditions on physicochemical properties of pine bark [19]. For further extractive processing, the optimal activation conditions were selected for both explosive autohydrolysis

$$
-305-
$$


and activation in a drum mill. The results obtained [19], showed that the mechanical activation allows us to increase the yields of extractive substances from pine bark by 1.5-2 times.

In the present study the pine bark was activated by explosive autohydrolysis at $120^{\circ} \mathrm{C}$, a water vapor pressure 1,0 $\mathrm{MPa}$ and an activation time $30 \mathrm{~s}$, and in a laboratory drum mill for 1 hour at room temperature. A decrease in the size of the bark particles was observed. The ratio of particles less than 1 $\mathrm{mm}$ in size was approximately $40 \%$. For the sample VAG the formation of large pores with a size 20 61 microns and small pores 8-13 microns was observed. Samples are described in more details in [19].

\section{Extraction of resinous substances from pine bark}

Resinous substances were isolated by hexane extraction in a Soxhlet apparatus from the original and activated pine bark. The processing time was varied from 4 to 16 hours. An almost linear growth of the extractive substances yields was observed up to $6 \mathrm{~h}$ for all samples (Fig. 1). For the original sample of pine bark after the extraction time 8-9 h graph gradually reaches to a plateau, while for the activated samples (MCA and VAG), a slight upward trend in the yields of extractive substances remains (Fig. 1).

\section{Isolation, identification and quantitative analysis of unsaponifiable substances}

The obtained resinous extracts were saponified in $\mathrm{NaOH}$ alcohol solutions. The concentration of alkali was varied as follows: $0.50,0.75,1.00 \mathrm{~N}$. Then unsaponifiable substances were extracted with diethyl ether, followed by separation of the ether fraction from water traces by freezing method.

The qualitative and quantitative composition of the resulting fraction was analyzed by GC-MS. About 40 substances were identified on chromatograms using mass spectra (Fig. 2). The highest intensity of the peaks was observed for the pine bark sample activated by explosion autohydrolysis (VAG). This may indicate that the activation increased the availability of extractives and resulted in their most complete extraction. The list of compounds with a content more than $1 \%$ isolated from the

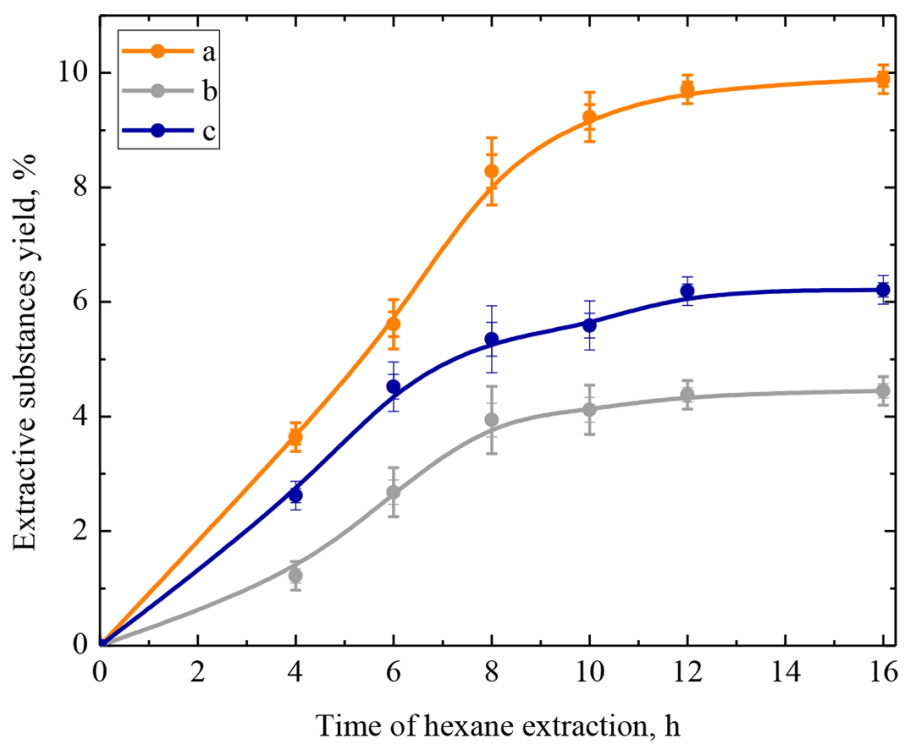

Fig. 1. Yields of the resinous substances versus hexane extraction time: a - pine bark activated by explosive autohydrolysis; $\mathrm{b}$ - pine bark activated by a drum mill; $\mathrm{c}$ - original pine bark 
pine bark activated by explosion autohydrolysis (VAG) is given in Table 1. All obtained substances are terpenes or their derivatives - terpenoids. Thus, $\alpha$ - and $\beta$-pinenes, $\beta$-pellandrene are monoterpenes, borneol is a monoterpenoid; $\beta$-bisabolic and $\alpha$-bisabolol are being sesquiterpene and sesquiterpenol; manoyl oxide, epimanool, sclareol, retinol - diterpenoids; stigmastan-3,5-diene, campesterol, $\beta$-sitosterol and stigmast-4-en-3-one are triterpenoids. Therefore, the fraction of unsaponifiable resinous substances from pine bark can be named as terpenoid fraction. The listed terpenes and terpenoids have a number of useful properties (biological activity, pleasant smell, lability to chemical transformations, etc.).Accordingly, the terpene fraction from pine bark can have great prospects for use in the pharmaceutical, perfumery, and cosmetic industries.

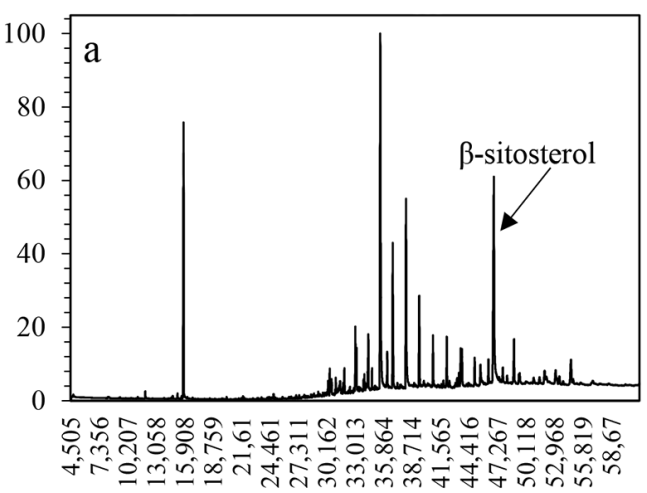

Retention time, min.

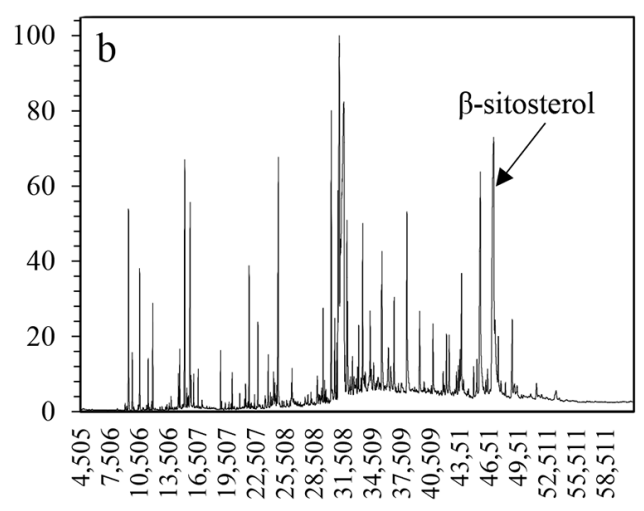

Retention time, min.

Fig. 2. Fragments of chromatograms for unsaponifiable substances of pine bark dissolved with diethylether: a sample of the original pine bark, $\mathrm{b}$ - pine bark activated by explosive autohydrolysis

Table 1. The components of ether fraction of saponified resinous substances, whose content exceeds $1 \%$ mas

\begin{tabular}{|c|c|c|c|}
\hline № & Retention time, min & Identified substances & Content, rel.\% \\
\hline 1 & 9,457 & $\alpha$-Pinene & 3,03 \\
\hline 2 & 10,607 & $\beta$-Pinene & 1,75 \\
\hline 3 & 11,961 & $\beta$-Phellandrene & 4,32 \\
\hline 4 & 15,254 & Borneol & 1,55 \\
\hline 5 & 21,883 & $\beta$-Bisabolene & 4,81 \\
\hline 6 & 24,888 & $\alpha$-Bisabolol & 1,12 \\
\hline 7 & 29,492 & Manoyloxide & 4,81 \\
\hline 8 & 30,342 & Epimanool & 1,92 \\
\hline 9 & 31,95 & Sclareol & 2,48 \\
\hline 10 & 33,58 & Retinol & 2,47 \\
\hline 11 & 43,76 & Stigmastan-3,5-diene & 8,60 \\
\hline 12 & 45,692 & Campesterol & 13,66 \\
\hline 13 & 47,05 & $\beta$-Sitosterol & 1,91 \\
\hline 14 & 48,98 & Stigmast-4-en-3-one & \\
\hline
\end{tabular}


The maximum peak area in the chromatograms was recorded for the substance with the retention time $47.05 \mathrm{~min}$. Its relative content in the terpene fraction was $13.66 \%$ for the pine bark activated by explosive autohydrolysis. Fig. 3 shows the recorded mass spectrum of this substance. Comparison the recorded mass spectrum with the available database showed that it is $\beta$-sitosterol (Fig. 3) and experiments with the analytical standard confirmed this conclusion. The characteristic peak at $\mathrm{m} / \mathrm{z} 396$ corresponds to the fragment ion caused by the release of water from the molecular ion.This correlates with literature data [20].

The quantitative yields of $\beta$-sitosterol in terpene fractions for the original sample of pine bark, the sample activated by explosive autohydrolysis (VAG) and activated in a drum mill (MCA) are given in the Table 2. The obtained data showed that an increase in the extraction time in hexane up to 8 hours raises the yield of $\beta$-sitosterol for original and treated samples of pine bark.Further increase in the time up to $16 \mathrm{~h}$ results in a decrease in the yield of $\beta$-sitosterol.This can be caused by the decomposition of this compound upon prolonged heating. An increase in the concentration of the saponifying alkali solution has a negative effect on the yield of $\beta$-sitosterol.

Activation of pine bark in a drum mill leads to an approximately 2 -fold increase in yield of $\beta$ sitosterol at short extraction time in hexane, a slight increase at medium time and a decrease at long time. Activation by explosive autohydrolysis also increases the yield of $\beta$-sitosterol; a more significant increase (more than 2 times) was observed at low alkali concentrations and shorter extraction times. The maximum amount of $\beta$-sitosterol $-0.078 \mathrm{wt} . \%$ of the weight of the dry activated bark sample was isolated at an extraction time 8 hours and an alkali concentration $0.5 \mathrm{~N}$. This amount is close to the total content of $\beta$-sitosterol in the pine bark known from the literature $(65-81 \mathrm{mg} / \mathrm{g}$ or $0.065-$ 0.081 wt.\%) [12].
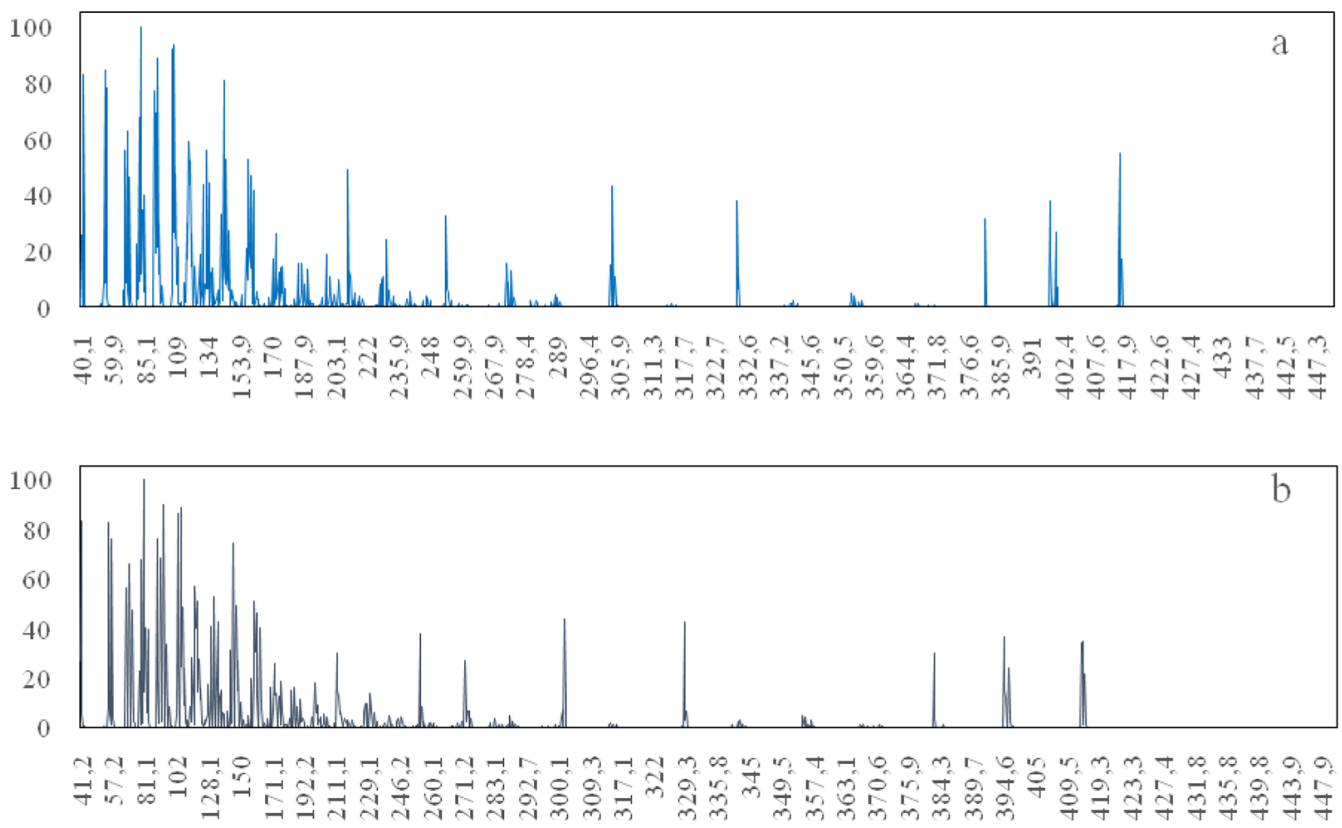

Fig. 3. Mass spectra registered for: $a$ - analytical standard of $\beta$-sitosterol (CAS Number: $83-46-5)$; $b-\beta$-sitosterol isolated from pine bark activated by explosive autohydrolysis 
Table 2. The yield of $\beta$-sitosterol after saponification of pine bark resinous substances

\begin{tabular}{|c|c|c|c|c|c|c|c|}
\hline $\begin{array}{l}\text { Hexane } \\
\text { extraction } \\
\text { time, } \mathrm{h}\end{array}$ & $\begin{array}{c}\text { Concentration } \\
\mathrm{NaOH} \\
\mathrm{N}\end{array}$ & $\begin{array}{l}\text { Sample of } \\
\text { pine bark }\end{array}$ & $\begin{array}{c}\beta \text {-sitosterol } \\
\text { yield, \%* }\end{array}$ & $\begin{array}{l}\text { Sample of } \\
\text { pine bark }\end{array}$ & $\begin{array}{c}\beta \text {-sitosterol } \\
\text { yield, } \% *\end{array}$ & $\begin{array}{l}\text { Sample of } \\
\text { pine bark }\end{array}$ & $\begin{array}{c}\beta \text {-sitosterol } \\
\text { yield, \%* }\end{array}$ \\
\hline 4 & 0,5 & \multirow{9}{*}{ Original } & 0,009 & \multirow{9}{*}{ VAG } & 0,025 & \multirow{9}{*}{ MCA } & 0,015 \\
\hline 4 & 0,75 & & 0,008 & & 0,013 & & 0,014 \\
\hline 4 & 1,0 & & 0,008 & & 0,005 & & 0,012 \\
\hline 8 & 0,5 & & 0,033 & & 0,078 & & 0,036 \\
\hline 8 & 0,75 & & 0,024 & & 0,057 & & 0,028 \\
\hline 8 & 1,0 & & 0,015 & & 0,038 & & 0,021 \\
\hline 16 & 0,5 & & 0,029 & & 0,034 & & 0,017 \\
\hline 16 & 0,75 & & 0,022 & & 0,027 & & 0,009 \\
\hline 16 & 1,0 & & 0,017 & & 0,019 & & 0,003 \\
\hline
\end{tabular}

* - from the mass of the original absolutely dry bark.

\section{Mathematical optimization of the $\beta$-sitosterol isolation process}

Based on the experimental data presented in Table 2, a mathematical optimization of the process of $\beta$-sitosterol isolation from pine bark was carried out. The following factors were chosen as independent variables: the duration of the extraction process $\left(\mathrm{X}_{1}\right)$ and the concentration of the $\mathrm{NaOH}$ in alcohol solution $\left(\mathrm{X}_{2}\right)$. As output parameter: $\mathrm{Y}_{1}-$ the $\beta$-sitosterol yield in wt.\%.was chosen. A combined multilevel experimental design (Users Design) was used.In calculation the dependences of $\beta$-sitosterol yield from the original pine bark $\left(\mathrm{Y}_{1}\right)$ and samples activated by explosive autohydrolysis - VAG $\left(\mathrm{Y}_{1}{ }^{\mathrm{VAG}}\right)$ and activated by a drum mill $\mathrm{MCA}\left(\mathrm{Y}_{1}{ }^{\mathrm{MCA}}\right)$ on the variable process factors are approximated by the following regression equations:

$$
\begin{aligned}
& \mathrm{Y}_{1}=-0.00805556+0.00901786 \mathrm{X}_{1}-0.02 \mathrm{X}_{2}-0.000340278 \mathrm{X}_{1}^{2}- \\
& -0.00135714 \mathrm{X}_{1} \mathrm{X}_{2}+0.008 \mathrm{X}_{2}^{2} \\
& \mathrm{Y}_{1}^{\mathrm{VAG}}=-0.0125278+0.0243363 \mathrm{X}_{1}-0.085 \mathrm{X}_{2}-0.00122569 \mathrm{X}_{1}^{2}+ \\
& +0.00160714 \mathrm{X}_{1} \mathrm{X}_{2}+0.0133333 \mathrm{X}_{2}^{2} \\
& \mathrm{Y}_{1}^{\mathrm{MCA}}=-0.00897222+0.0108185 \mathrm{X}_{1}-0.015 \mathrm{X}_{2}-0.0005 \mathrm{X}_{1}^{2}- \\
& -0.00153571 \mathrm{X}_{1} \mathrm{X}_{2}+0.00533333 \mathrm{X}_{2}^{2}
\end{aligned}
$$

The predictive properties of equations $(1,2,3)$ are clearly demonstrated in Fig. 4, which compares the values of the output parameters $\mathrm{Y}$ obtained in the experiment with the values calculated from the equations. The straight line corresponds to the calculated values of $\mathrm{Y}$, the points correspond to the experimental results. The closeness of the experimental and calculated values to the straight line confirms the high degree of approximation for the equations $1-3$. The mathematical model was used to visualization the response surfaces of the output parameter $\mathrm{Y}_{1}$ on the variable factors $X_{1}$ and $X_{2}$ (Fig. 5).

Variance analysis for the original pine bark (Table 3) showed that under the chosen experimental conditions, the extraction time makes the highest contribution to the total variance of the output parameter, as indicated by the high value of the dispersion ratios $\mathrm{F}$ and the low value of the significance

$$
-309-
$$


a

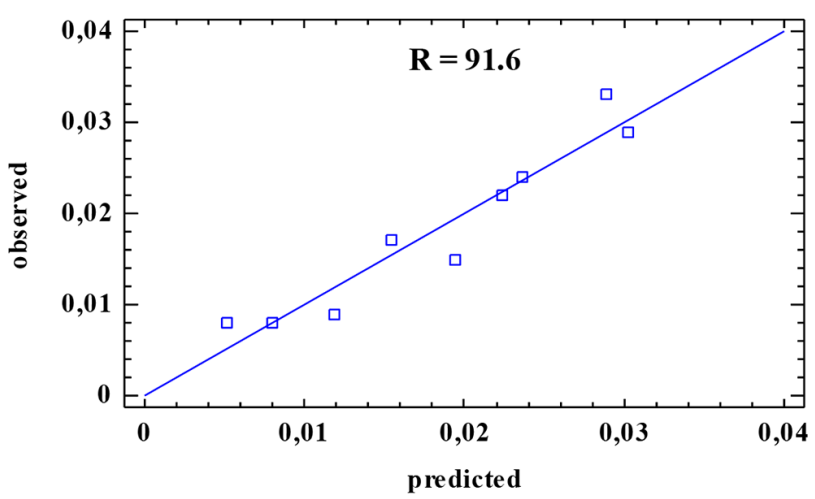

b

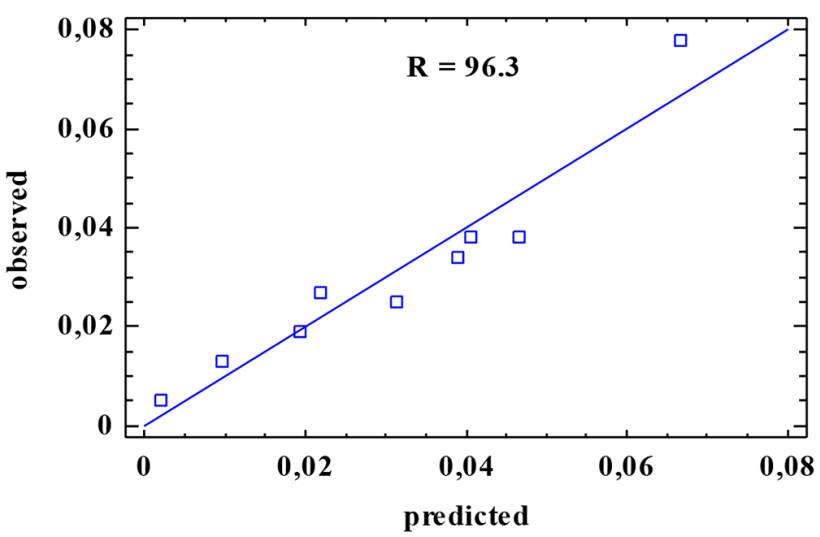

C

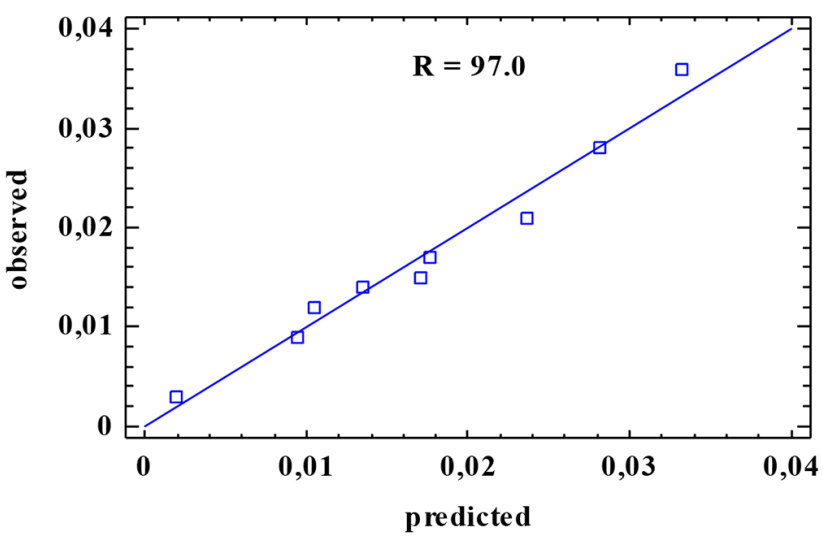

Fig. 4. Graph predicted by the model and observed in the experiment values of the output parameter ( $\beta$-sitosterol yield): $\mathrm{a}$ - original pine bark; $\mathrm{b}$ - bark activated by explosive autohydrolysis; $\mathrm{c}$ - bark, activated in a drum mill

level P. Variance analysis for mechanically activated pine bark (VAG and MCA) (Table 3) showed the highest contribution of the concentration $\mathrm{NaOH}$ in alcohol solution to the total dispersion of the output parameter under the explored conditions. This is indicated by the high values of the dispersion ratios F for the main effects. The information in the columns $\mathrm{P}$ (Table 3 ) is interpreted in a similar way. The influence of the source of variance on the output parameter is considered statistically significant if the significance level is less than the specified critical value. 
a

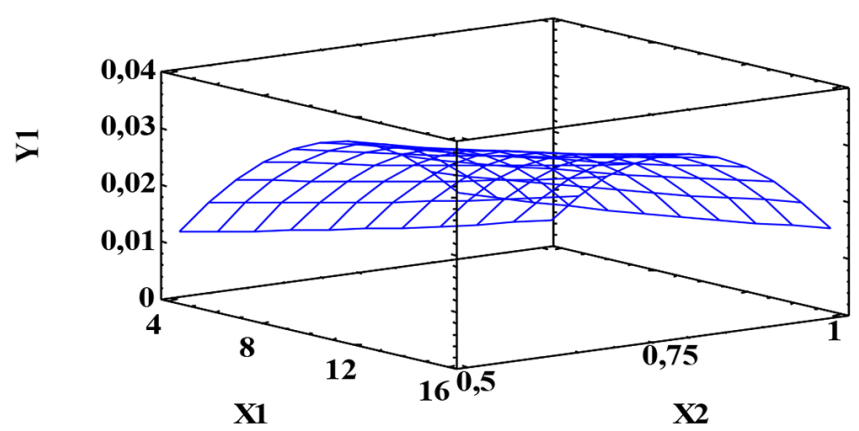

b

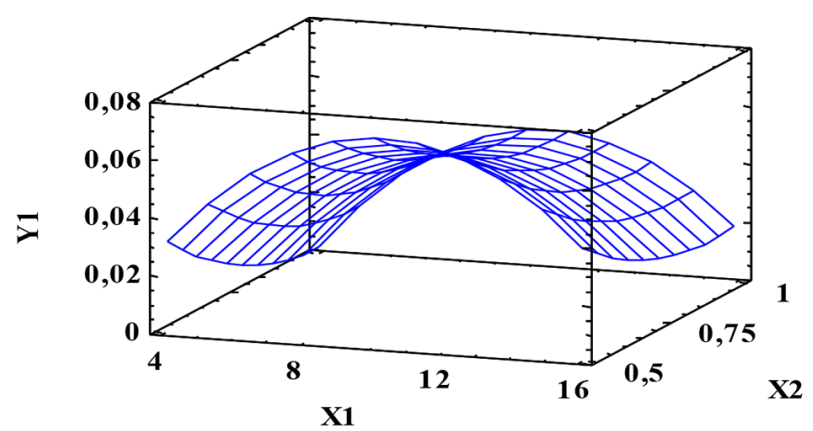

C

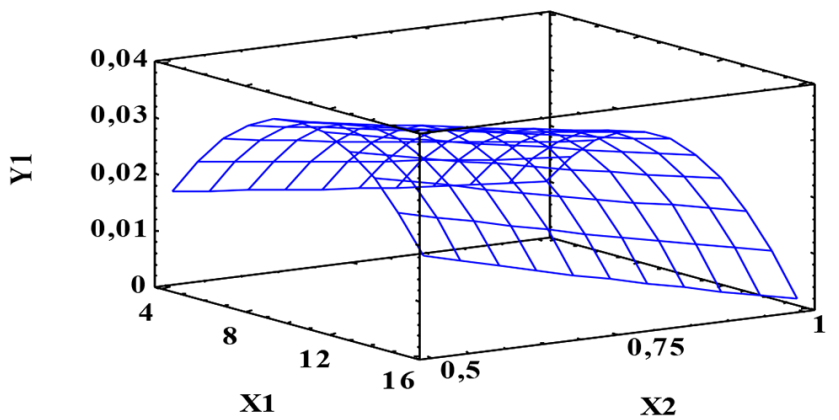

Fig. 5. Response surfaces of the output parameter ( $\beta$-sitosterol yield): $a$ - original pine bark; $b$ - bark activated by explosive autohydrolysis; $\mathrm{c}$ - bark, activated in a drum mill

Table 3. The results of dispersion analysis of the extraction processes original bark sample, bark sample VAG, bark sample MCA

\begin{tabular}{|c|c|c|c|c|c|c|}
\hline Sample & \multicolumn{2}{|c|}{ Original } & \multicolumn{2}{c|}{ VAG } & \multicolumn{2}{c|}{ MCA } \\
\hline $\begin{array}{c}\text { Dispersion } \\
\text { sources }\end{array}$ & $\begin{array}{c}\text { Dispersion } \\
\text { ratio } \\
\mathrm{F}\end{array}$ & $\begin{array}{c}\text { Significance } \\
\text { level } \\
\mathrm{P}\end{array}$ & $\begin{array}{c}\text { Dispersion } \\
\text { ratio } \\
\mathrm{F}\end{array}$ & $\begin{array}{c}\text { Significance } \\
\text { level } \\
\mathrm{P}\end{array}$ & $\begin{array}{c}\text { Dispersion } \\
\text { ratio } \\
\mathrm{F}\end{array}$ & $\begin{array}{c}\text { Significance } \\
\text { level } \\
\mathrm{P}\end{array}$ \\
\hline $\mathrm{X}_{1}$ & 16,08 & 0,0278 & 4,47 & 0,1248 & 3,12 & 0,1757 \\
\hline $\mathrm{X}_{2}$ & 8,95 & 0,0581 & 17,29 & 0,0253 & 23,92 & 0,0164 \\
\hline $\mathrm{X}_{1}{ }^{2}$ & 11,94 & 0,0408 & 58,17 & 0,0047 & 64,12 & 0,0041 \\
\hline $\mathrm{X}_{1} \mathrm{X}_{2}$ & 0,9 & 0,4134 & 0,47 & 0,5411 & 2,86 & 0,1895 \\
\hline $\mathrm{X}_{2}{ }^{2}$ & 0,03 & 0,8819 & 0,03 & 0,8794 & 0,03 & 0,8759 \\
\hline $\mathrm{R}_{\text {adj }}^{2}$ & \multicolumn{2}{|c|}{91,6} & 96,3 & & 97,0 \\
\hline
\end{tabular}


The maximum predicted value of the $\beta$-sitosterol yield was 0.035 (wt.\%) for the original pine bark in the explored factor space.It could be reached at the following values of variable factors: process duration 12.3 hours, concentration of $\mathrm{NaOHin}$ solution $0.5 \mathrm{~N}$. For the pine bark activated by explosion autohydrolysis, the maximum predicted value of the $\beta$-sitosterol yield is 0.078 (wt.\%), at the following values of variable factors: the process duration 10.3 hours, the concentration of the saponification $\mathrm{NaOH}$ solution $0.5 \mathrm{~N}$. For the pine bark activated in drum mill, the maximum predicted value of $\beta$-sitosterol yield is 0.035 , at the following values of variable factors: process duration 10.1 hours, concentration of saponifying $\mathrm{NaOH}$ solution $0.5 \mathrm{~N}$.

Results of mathematical optimization for activated bark of the process of resinous substances extraction shows that the shorter extraction time is required to achieve maximum yield of $\beta$-sitosterol (wt.\%) compared to the original bark. Also for mechanically activated pine bark (VAG and MCA), the concentration of $\mathrm{NaOH}$ in the saponification solution is more important than the duration of the hexane extraction.

\section{Conclusion}

The mechanical activation of pine bark in a drum mill as well as by explosive autohydrolysis increases by 1.5-2 times the yield of extractive substances compared to the original bark.

The unsaponifiable resinous products were isolated from pine bark by treatment with $\mathrm{NaOH}$ alcohol solutions and further extraction with diethyl ether.Accroding to GC-MS data about 40 substances have been identified in resinious products, including mono-, di- and triterpenes and terpenoids. The main component of the terpene fraction was identified as $\beta$-sitosterol with a relative content of up to $13,66 \%$.

Experimental and mathematical optimization of the process of $\beta$-sitosterol isolation from original and activated pine bark was carried out.

The highest $\beta$-sitosterol yield ( $0.078 \mathrm{wt} . \%)$ was achieved using a pine bark activated by explosive autohydrolysis under the following optimal conditions: the duration of the process -10.3 hours, the concentration of the saponification solution of $\mathrm{NaOH}-0.5 \mathrm{~N}$. This yield is very close to the content of $\beta$-sitosterol in pine bark (0.065-0.081 wt.\%).

\section{Acknowledgements}

The reported study was funded by RFBR, Krasnoyarsk Territory Government and Krasnoyarsk Regional Fund of Science, project number 19-43-240011 and within the framework of the budget project (No. 0287-2021-0017) for Institute of Chemistry and Chemical Technology SB RAS using the equipment of Krasnoyarsk Regional Research Equipment Centre of SB RAS.

\section{References}

1. Мельман И.В. Лесопромышленный комплекс Красноярского края и проблема повышения его конкурентоспособности. Региональная экономика: теория и практика. 2008. T. 26, C. 29-35. [Melman I. V. Krasnoyarsk region timber industry complex and the problem of increasing its competitiveness. Regional economy: theory and practice 2008. Vol. 26, P. 29-35. (In Russ.)]

2. Соболев С.В., Трофимук В.Н. Проблемы комплексности использования сырья

деревообрабатывающих предприятиях Красноярского края. Усnехи современного 
естествознания. 2004. С. 168-171. [Sobolev S. V., Trofimuk V.N. Krasnoyarsk Territory raw materials use complexity problems at wood-processing enterprises. Success of modern natural science 2004. P. 168-171 (In Russ.)]

3. Abilleira F., Varela P., Cancela Á., Álvarez X., Sánchez Á., Valero E., Tannins extraction from Pinuspinaster and Acacia dealbata bark with applications in the industry. Industrial Crops and Products, 2021. 164: p. 113394.

4. Gao Y., Wang S., Dang S., Han S., Yun C., Wang W., Wang H. Optimized ultrasoundassisted extraction of total polyphenols from Empetrumnigrum and its bioactivities. Journal of Chromatography B, 2021. 1173: p. 122699.

5. Wu K., J T., Deng Y., Xi J. Mechanochemical assisted extraction: A novel, efficient, ecofriendly technology. Trends in Food Science \& Technology, 2017. 66: p. 166-175.

6. Anastas P. and N. Eghbali, Green Chemistry: Principles and Practice. Chemical Society Reviews, 2010. 39(1): p. 301-312.

7. Babu S. and S. Jayaraman, An update on $\beta$-sitosterol: A potential herbal nutraceutical for diabetic management. Biomedicine \& Pharmacotherapy, 2020. 131: p. 110702.

8. Panayotis N., Freund P.A., Marvaldi L., Shalit T., Brandis A., Mehlman T., Tsoory M. M., Fainzilber M. $\beta$-sitosterol reduces anxiety and synergizes with established anxiolytic drugs in mice. Cell Reports Medicine, 2021. 2(5): p. 100281.

9. Cheng Y., Chen Y., Li J., Qu H., Zhao Y., Wen C., Zhou Y.,, Dietary $\beta$-sitosterol regulates serum lipid level and improves immune function, antioxidant status, and intestinal morphology in broilers. Poultry Science, 2020. 99(3): p. 1400-1408.

10. Santos K.A., Klein E. J., Fiorese M.L., Palú F., da Silva C., da Silva E. A., Extraction of Morus alba leaves using supercritical $\mathrm{CO}_{2}$ and ultrasound-assisted solvent: Evaluation of $\beta$-sitosterol content. The Journal of Supercritical Fluids, 2020. 159: p. 104752.

11. Kuznetsov B.N., Efremov A.A., Levdanskii V.A., Kuznetsova S.A., Polezhaeva N.I., Shilkina T.A., Krotova I.V. The use of non-isobaric pre-hydrolysis for the isolation of organic compounds from wood and bark. Bioresource Technology, 1996. 58(2): p. 181-188.

12. Дейнеко И.Н., Дейнеко.И.В., Белов Л.П. Исследованиехимического состава коры сосны. Химия растительного сырья, 2007. 1. C. 19-24. [Deineko I.N., Deineko I. V., Belov L.P. Study of the chemical composition of pine bark. Khimija Rastitel'nogo Syr'ja, 2007.1: p. 19-24 (In Russ.)]

13. Bukhanko N., Attard T., Arshadi M., Eriksson D., Budarin V., Hunt A.J., Geladi P., Bergsten U., Clark J. Extraction of cones, branches, needles and bark from Norway spruce (Piceaabies) by supercritical carbon dioxide and soxhlet extractions techniques. Industrial Crops and Products, 2020. 145: p. 112096.

14. Lopez-Tenllado F.J., Motta I.L., and Hill J.M., Modification of biochar with high-energy ball milling: Development of porosity and surface acid functional groups. Bioresource Technology Reports, 2021. 15: p. 100704.

15. Guo L., Hu Z., Du Y., Zhang T.C., Du D. Mechanochemical activation on selective leaching of arsenic from copper smelting flue dusts. Journal of Hazardous Materials, 2021. 414: p. 125436.

16. Казаченко А.С., Васильева Н.Ю., Судакова И.Г., Левданский В.А., Лутошкин М.А., Кузнецов Б. Н.. Численная оптимизация процесса сульфатирования этаноллигнина древесины пихты сульфаминовой кислотой в среде 1,4-диоксана в присутствии мочевины. Журн. 
Сиб. федер. ун-та. Химия, 2020. 13(2) [A.S. Kazachenko, N. Y. Vasilyeva., I. G. Sudakova, V.r A. Levdansky, M.A. Lutoshkin, B.N. Kuznetsov, Numerical Optimization of the Abies Ethanol Lignin Sulfation Process with Sulfamic Acid in 1,4-Dioxane Medium in the Presence of Urea. Journal of Siberian Federal University. Chemistry, 2020. 54(2): p. 232-246 (in Russ.)].

17. Пен Р.3. Планирование эксперимента в Statgraphics Centurion. Красноярск: СибГТУ, 2014. 291 c. [Pen R.Z., Planning an experiment at Statgraphics Centurion. Krasnoyarsk: SibSTU, 2014. 291 p. (In Russ.)].

18. Болдырев В.В., Аввакумов Е.Г., Болдырева Е.В. Фундаментальные основы механической активации, механосинтеза и механохимических технологий. Новосибирск: Издательство CO PAH, 2009(19). 343 с. [Boldyrev V.V., Avvakumov E. G., Boldyreva E.V. Fundamentals basis of mechanical activation, mechanosynthesis and mechanochemical technologies; Novosibirsk: SB RAS Publishing, 2009 (19). 343 p (In Russ.)].

19. Веприкова Е.В., Ионин В.А., Белаш М.Ю., Скрипников А.М., Левданский А.В., Таран О.П. Влияние различных способов механической активации на выход экстрактивных веществ из коры сосны. Журн. Сиб. федер. ун-та. Химия, 2020. 13(3). С. 430-446. [Veprikova E. V., Ionin V. A., BelashM.Yu., Skripnikov A. M., Levdanskii A. V., Taran O. P. Influence Different Methods of Mechanical Activation on Yield Extractive Substances from Pine Bark. Journal of Siberian Federal University. Chemistry, 2020. 13(3): p. 430-446. (In Russ.)].

20. Huang L., Zhong T., Chen T., Ye Z., Chen G., Identification of beta-sitosterol, stigmasterol and ergosterin in A. roxburghii using supercritical fluid extraction followed by liquid chromatography/ atmospheric pressure chemical ionization ion trap mass spectrometry. Rapid Commun Mass Spectrom, 2007. 21(18): p. 24-32. 